\title{
Conflict in Schools: A Qualitative Study
}

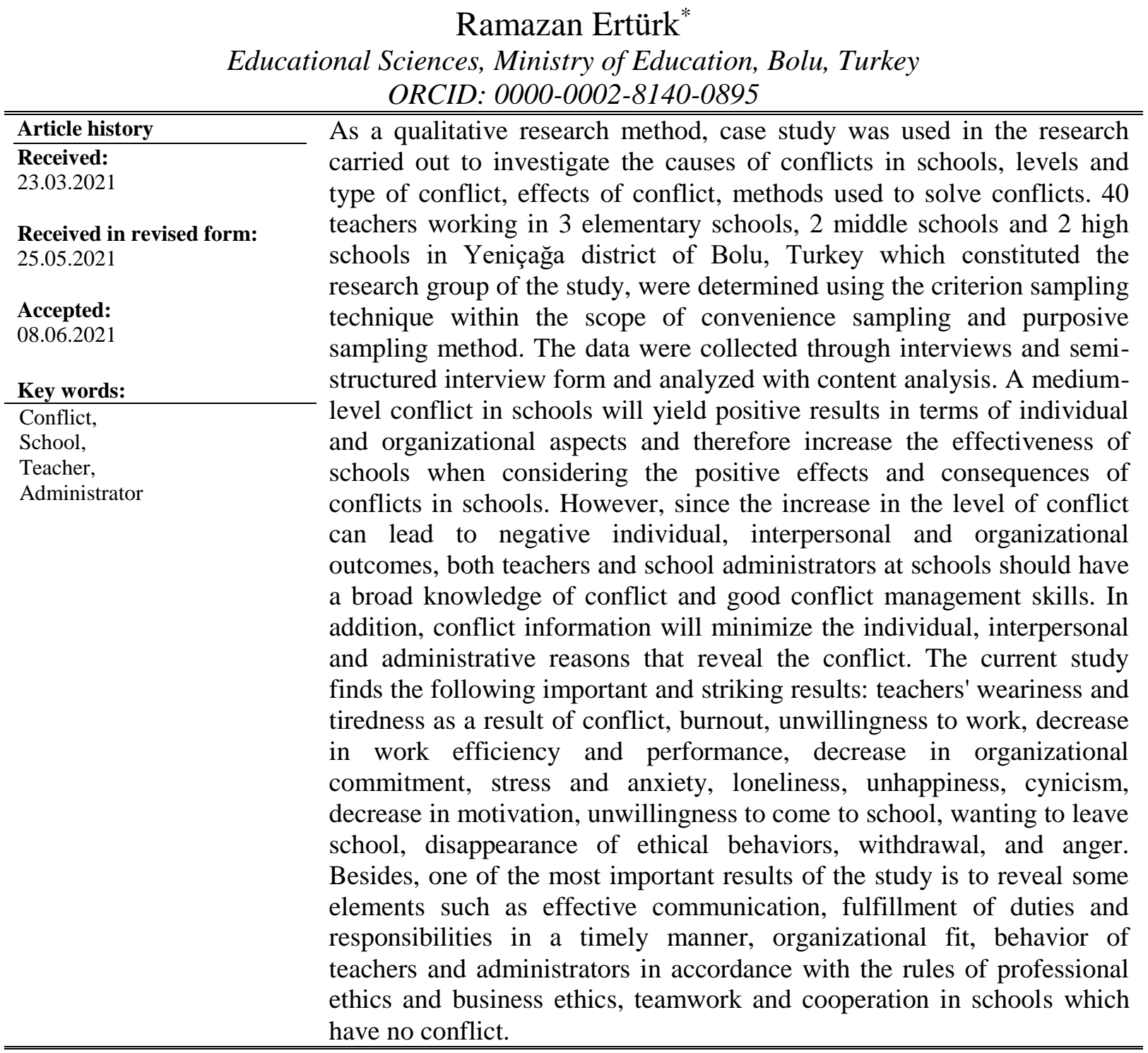

\section{Introduction}

In organizations which contain intensive human interactions, it is likely to witness disagreement, inconsistency and incompatibility in facilities and relationships among employees who constantly interact with each other in order to achieve the organizational

\footnotetext{
*Correspondency: koroglu522@hotmail.com
} 
goals. These situations can cause conflict. Human relations are also experienced intensively in schools, which are one of the most important educational organizations. Administrators, teachers, students, parents and other employees are in constant communication and interaction in order for educational facilities to reach success. Therefore, it could be assumed as natural to have disagreements, discussions and incompatibilities in schools which are in the center of human resources.

Conflict can occur in all aspects of social life. The input, process and output of school organizations which are a small model of social life and open systems consist of human beings. Therefore, conflicts in schools occur more realistically and concretely (Sarpkaya, 2002). Conflict is an interactive process involving disagreement, discrepancy or incompatibility between two or more individuals or groups in any subject (Koçel, 2005; Rahim, 2002), it is the dispute resulted by the non-matching interests between two interdependent parties (Leung, 2008) and it is the fact that the interests of the parties which arise due to different value judgments, objectives, goals or lack of communication, change, deviation that hinder each other (Moisogluo, Prezerakis, Galanis, Siskou, Maniadakis, \& Dafni, 2014). Conflict is generally caused by problems between individuals or groups working together. These problems may cause disruption or complete cessation of normal functioning in the working environment or current environment (Eren, 2008). Conflict arises when an individual has one or two responses toward a phenomenon or situation and when there are non-matching options and rivalry. In addition, there are many activities such as management of educational activities, clubs, celebrating certain days and weeks, schoolfamily cooperation, meetings, and others that need to be carried out to achieve the objectives in schools. All school stakeholders must be in touch in the process of implementation of these activities as it is not possible to carry out them with the help of a single person. Therefore, problems may occur in communication because people's emotions, personal characteristics and desires may be different. These problems caused by communication can lead to the emergence of conflict (Ertürk, 2019). The conflict is perceived as a bad situation that needs to be suppressed, but it also has positive consequences if managed well. It is important to be qualified about the management of the conflict and how to deal with it constructively as it is not a completely a good or bad situation (Öner-Körüklü, 2010; Weitten, Yost-Hammer \& Dunn, 2016). The conflicts which are not managed well can be destructive and cause serious harm. As a matter of fact, a conflict process which is not managed well can lead to negative feelings and situations such as rivalry in group targets, interdependence, decreased cooperation and stability (Turan, 2014); blood pressure, irritability, anger, stress, hostile attitudes, demoralization, decrease in work motivation and satisfaction, decreased energy, efficiency and organizational commitment, polarization and absenteeism (Genç, 2005; Şimsek $\&$ Çelik, 2008). On the other hand, a well-managed conflict has positive effects and results. Organizational relations become more positive and stronger as employees can easily express their feelings and thoughts thanks to conflict. Conflict allows employees to listen to each other, accept each other's thoughts and get rid of being egocentric and reach psychological maturity. Employees strive in areas where they can get better results to be more efficient and successful in their work. The conflict ensures the questioning of objectives and organizational structure; developing necessary working environment for change and areas where employees can succeed (Karip, 2000). As for schools, teachers also want to take part in facilities which they succeed in. However, teachers sometimes could be assigned duties which they do not want, which in turn result in a conflict at schools.

It is not possible for activities to be carried out in schools by a single person. Therefore, the communication of all stakeholders of the school is to ensure that the school is effective and 
efficient. However, there may be problems between students, teachers, administrators and parents who have different desires, emotions and personalities for various reasons. In this case, a conflict between individuals arises, which in turn have positive or negative consequences and effects. For the negative consequences of the conflict as well as its positive effects and consequences to be evaluated, the causes of the conflict must first be revealed through examining these in depth as the emerging reasons will help the parties decide what kind of strategy and tactics to resolve it. Minimizing the negative effects of the conflict process and completing it successfully requires teachers and administrators to have adequate knowledge of conflict and negotiation. However, first, it is necessary to reveal the situations that cause conflict in schools, the consequences and effects and methods to deal with it. When the studies are examined (Okotoni \& Okotoni, 2003; Corvette, 2007; Fabunimi \& Alimba, 2010; Koçak, 2012; Msila, 2012; Uchendu, Anijaobi-Idem, \& Odigwe, 2013; Bayar, 2015; Konak \& Erdem, 2015; Demirdağ , 2016; Vaiz, 2017; Özdemir, 2018; Kurt, 2019; Şimşek, 2019; Akgöz \& Cemaloğlu, 2020), it is striking that the causes of conflict and conflict management strategies are generally focused and the studies are quantitative studies. In this study, the causes of conflicts, the level and type of conflicts, their effects and results, the methods used in the resolution and management of conflicts, the reasons for not experiencing conflict in schools where there is no conflict were examined in detail and the subject was examined in a holistic manner. Therefore, the research is an original study as it enables the reader to see and read the subject in its entirety. In this context, it is aimed to investigate the causes of conflicts in schools, levels and types, effects and methods used to solve them. It is thought that the results and recommendations will shed light on school administrators and teachers, as well as researchers, and that the research will contribute to the field of management of education. Taking these into consideration, research questions were addressed as below for teachers:

(1) What are their views on the causes of conflicts at schools?

(2) What are their views on situations that ensure a non-conflict environment at the schools where there is no conflict?

(3) What are their views on the level and type of conflicts at schools?

(4) What are their views on the negative effects of conflicts at schools?

(5) What are their views on the positive effects of conflicts?

(6) What are their views on the methods used in the management and resolution of conflicts?

\section{Method}

\section{Research Design}

The research was conducted using a case study which is a qualitative study design. The case study conducts an in-depth investigation based on data on any event, individual or process (Creswell, 2007). Case study is a method which investigates the case in the existing environment, and it is used for cases where the current situation and the environment which it is in are not detailed and more than one data source is present, and it gives researchers the opportunity to examine the case in depth by focusing on how and why (Yin, 2003).

\section{Study Group}

The study group contains 40 teachers working in 3 elementary schools, 2 secondary schools and 2 high schools in Yeniçağa district of Bolu, Turkey. Determining the study group 
was based on a voluntary basis convenience sampling, which allows researchers to be quick and practical (Baki \& Gökçek, 2012; Yıldırım \& Şimsek, 2015) and criterion sampling, which provides details for a specific purpose and to obtain rich data (Teddlie \& Tashakkori, 2015). Therefore, in the study, it was taken as a criterion that teachers must have conflict in their schools to be able to express their views about the causes of conflict, the effects of conflict, the level and type of conflict and management methods. In this context, 28 teachers were interviewed. In order to reveal what the elements are that prevent conflicts in schools where there is no conflict, it was taken as a criterion that the teachers who were determined voluntarily did not have conflicts in their schools, and 12 teachers were interviewed in this context.

\section{Instruments and Data Collection Procedure}

The data of the research were collected through interviews and using a semi-structured interview form consisting of open-ended items. Semi-structured forms are a flexible and important tools that allow the researcher to ask additional questions (Büyüköztürk, KıliçÇakmak, Akgün, Karadeniz, \& Demirel, 2012) and explore the participants' experiences during the interview (Rabionet, 2011). In the process of developing the data collection tool, the related literature was reviewed first and the draft interview form consisting of 5 openended questions was prepared. The interview form, then, was presented to the 3 faculty members who are experts in the field of educational administration and assessment and evaluation. After the experts indicated that the interview form consisted of two main questions and auxiliary questions designed in accordance with the problem situation and the research design adopted by the researcher, revisions were made on the interview form and pilot study was carried out by administrating it to 6 teachers who were not in the study group. In the pilot study, the questions were found to be understandable and the interview form was finalized upon evaluating the results with the experts. The teachers were given the necessary information about the questions. The interview with each teacher in the study group lasted an average of 17 minutes. This research was examined in the Ethics Committee of Human Studies in Social Sciences at Bolu Abant Izzet Baysal University and was found ethically appropriate.

\section{Data Analysis}

The data was grouped around specific themes and analyzed with content analysis, which enables the data to be interpreted in a way that the reader could understand. Within the scope of content analysis, data are analyzed by investigating it systematically after grouping similar data (Yıldırım \& Şimşek, 2015). The data obtained from the interview were read in detail in line with the purpose and questions of the research, and they were coded. After coding, the themes were determined by examining the similarities and differences between the codes that had a significance to each other. The results were supported by giving the teachers' opinions as direct quotes in the findings section.

\section{Validity and Reliability}

In qualitative studies, the clear and comprehensible questions about ensuring the reliability associated with the consistency of investigation and coding provide insight into the consistency of the study (Creswell, 2007). The codes and themes created to ensure the reliability were examined by 2 expert faculty members in the fields of assessment and evaluation, educational administration, then it was checked whether the codes complied with the themes. Within the scope of determining the reliability, Miles and Huberman's (1994) 
formula [Consensus/(Dissensus+Consensus) X 100] was used, and the reliability score was found to be $91 \%$. It can be stated that the analyses are reliable since the reliability of $80 \%$ and above is considered acceptable. In order to ensure content validity, the teachers' views were presented as direct quotes. To increase the construct validity; the design of the study, sampling criteria, data collection tool and data analysis were explained in detail in the method section.

\section{Findings}

The views of 28 teachers who stated that there was a conflict at their schools are shown in Table 1.

Table 1. Causes of conflicts at schools

\begin{tabular}{|c|c|c|}
\hline Themes & Codes & $\mathbf{f}$ \\
\hline \multirow{6}{*}{ Personal Factors } & Prejudice & 13 \\
\hline & Personality differences & 12 \\
\hline & Low motivation & 10 \\
\hline & Being Manipulative & 7 \\
\hline & Not being honest and sincere & 7 \\
\hline & Unwillingness to learning & 6 \\
\hline \multirow{14}{*}{$\begin{array}{l}\text { Interpersonal } \\
\text { Factors }\end{array}$} & Negative communication & 14 \\
\hline & Groupings & 12 \\
\hline & Not recognizing newcomers & 10 \\
\hline & The ambition of success in teachers & 9 \\
\hline & Not welcoming criticism & 8 \\
\hline & Jealousy of success and qualifications of others & 7 \\
\hline & The desire of individuals to be at the forefront all the time & 6 \\
\hline & Gossip and rumor & 6 \\
\hline & Having different ideas & 5 \\
\hline & Misunderstanding & 5 \\
\hline & False and incriminating accusations of individuals & 4 \\
\hline & Not being respectful to others' opinions & 3 \\
\hline & Avoiding work & 2 \\
\hline & The presence of teachers with professional inexperience & 1 \\
\hline \multirow{10}{*}{$\begin{array}{l}\text { Administrative } \\
\text { Factors }\end{array}$} & Poor leadership skills & 16 \\
\hline & Lack of proficiency in the field of educational administration & 14 \\
\hline & Favoritism & 12 \\
\hline & The desire of administrators to be obeyed by all means & 11 \\
\hline & Dominating behavior & 11 \\
\hline & Not accepting intervention & 10 \\
\hline & Neglecting teachers' thoughts & 9 \\
\hline & Adopting an autocratic and refraining management & 9 \\
\hline & Not fulfilling duties and responsibilities & 8 \\
\hline & Tending to advocate some teachers individually & 4 \\
\hline \multirow{5}{*}{ Other Factors } & Giving the workload to certain employees & 17 \\
\hline & Insufficient resources & 11 \\
\hline & Not fulfilling duties and responsibilities by teachers & 9 \\
\hline & Power discrepancy between administrators and teachers & 8 \\
\hline & The presence of teachers with different years of experience & 6 \\
\hline
\end{tabular}

As illustrated in Table 1, the causes of conflicts in schools were grouped under the themes such as individual, interpersonal, administrative and other factors. Individual factors causing conflict in schools were determined as prejudice $(f=13)$, personality differences $(f=12)$, low motivation ( $\mathrm{f}=10$ ), being manipulative $(\mathrm{f}=7)$, not being honest and sincere $(\mathrm{f}=7)$, and unwillingness to learning. 
Interpersonal factors were emerged as negative communication $(\mathrm{f}=14)$, groupings $(\mathrm{f}=12)$, not recognizing newcomers $(\mathrm{f}=10)$, the ambition for success in teachers $(\mathrm{f}=9)$, not welcoming criticism $(\mathrm{f}=8)$, jealousy of success and qualifications of others $(\mathrm{f}=7)$, the desire of individuals to be at the forefront all the time $(\mathrm{f}=6)$, gossip and rumor $(\mathrm{f}=6)$, having different ideas $(\mathrm{f}=5)$, misunderstanding ( $\mathrm{f}=5$ ), false and incriminating accusations of individuals $(\mathrm{f}=4)$, not being respectful to others' opinions ( $\mathrm{f}=3$ ), avoiding work $(\mathrm{f}=2)$, the presence of teachers with professional inexperience $(\mathrm{f}=1)$.

Administrative factors causing conflicts in schools were determined as poor leadership skills $(\mathrm{f}=16)$, lack of proficiency in the field of educational administration $(\mathrm{f}=14)$, favoritism $(\mathrm{f}=12)$, the desire of administrators to be obeyed by all means $(\mathrm{f}=11)$, dominating behavior $(\mathrm{f}=11)$, not accepting intervention ( $\mathrm{f}=10)$, neglecting the teachers' thoughts $(\mathrm{f}=9)$, adopting an autocratic and refraining management $(\mathrm{f}=9)$, not fulfilling duties and responsibilities $(\mathrm{f}=8)$ tending to advocate some teachers individually $(\mathrm{f}=4)$.

Other causes of the conflicts in schools were emerged as giving the workload to the certain employees ( $\mathrm{f}=17)$, insufficient resources $(\mathrm{f}=11)$, not fulfilling duties and responsibilities by teachers $(\mathrm{f}=9)$, power discrepancy between administrators and teachers $(\mathrm{f}=8)$, and the presence of teachers with different years of experience $(\mathrm{f}=6)$.

Some of the views of the teachers stating that there is a conflict at their school on the causes of conflicts are presented below in direct quote:

"Yes, there are conflicts. Causes such as the biased behavior of the staff, the low competence of the administrators in the management, the ambition of success among the teachers, the presence of teachers with different years of experience can lead to conflict. In addition, it could also be a cause for conflict to give the duties which nobody wants to the newly arrived teachers." (T15), "Yes, there are conflicts. Our school is crowded. It is impossible to expect everyone to agree on everything. The conflicts between the administrator and the teacher are usually caused by delayed or incomplete fulfillment of duties by administrators." (T1), "Teachers competing and making comparisons in issues related to their classrooms can lead to conflict. It can also be caused when individuals do not respect the opinions other than their own." (T7), "Yes, it (conflict) occurs. There are conflicts stemming from neglecting the teachers' thoughts by the school administration, lack of understanding of their thoughts, the desire of administrators to be respected in all their statements and not being able to communicate in a healthy way." (T6), "Conflicts arising from the authoritarian and refraining management style of the school administrator are common." (T18), "That some teachers in our school are more competent than the school administrator and the existence of direct teachers can cause conflict with the school administrator" (T35).

The views of 12 teachers indicating that there are no conflicts at their schools on the factors ensuring a non-conflict environment are presented below in Table 2. 
Table 2. Factors ensuring no conflicts in schools with no conflicts

\begin{tabular}{lll}
\hline Themes & Code & f \\
\hline & Effective communication & 9 \\
& Fulfilling everyone's duties and responsibilities on time & 7 \\
& Organizational harmony (administrator-employee) & 6 \\
& Not objecting to the given task & 5 \\
& Small number of employees & 4 \\
\hline
\end{tabular}

As seen in Table 2, analyzing the views of the teachers $(n=11)$ who stated that there were no conflicts at their schools, it was determined that the factors ensuring no conflicts consist of effective communication ( $\mathrm{f}=9$ ), fulfilling everyone's duties and responsibilities on time $(\mathrm{f}=7)$, organizational harmony (administrator-employee) $(\mathrm{f}=6)$, not objecting to the given task $(\mathrm{f}=5)$, small number of employees $(\mathrm{f}=4)$, teachers and administrators acting in accordance with the rules of professional ethics and work ethics ( $\mathrm{f}=2)$, ensuring cooperation through teamwork $(\mathrm{f}=2)$, ensuring sustainability in professional development $(\mathrm{f}=1)$. When asked in what areas teachers and administrators followed the rules of professional ethics and business ethics, especially in accordance with the related response of theirs, the teachers stated that school administrators were striving to create a democratic school environment with love, respect and tolerance by acting in a fair and impartial way without favoring anybody, and that teachers and administrators struggled to fulfill their professions in a professional way.

Some of the views of the teachers stating that there is no conflict at their school on the causes of conflicts are presented below as direct quote:

"There is no conflict in our school as effective communication is ensured" (T11), "Since there is teamwork and cooperation between administrators and teachers, there is no conflict because everyone fulfills their duties and responsibilities." (T4), "There is no conflict in our school because the teachers and administrators act in accordance with the rules of professional ethics." (T12), "There is no conflict in our school because the number of staff is small." (T19), "There is no conflict in our school because the school administration and teachers work in harmony. All staff carry out the facilities in cooperation without objecting to the given tasks." (T33), "Our school administrators show fair, impartial and democratic attitudes and behaviors. They are trying to create a democratic environment dominated by love, respect and tolerance without favoring anyone. Furthermore, both teachers and administrators strive to do their jobs professionally. They care about professional development." (T37).

The views of teachers on the level and type of the conflicts at schools are shown in Table 3.

Table 3. The level and type of the conflict

Levels of conflict Type of conflict

\begin{tabular}{lllll}
\hline Themes & Codes & f & Codes & f \\
\hline \multirow{3}{*}{ Vertical } & Administrator-teacher & 21 & Argument & 26 \\
& Teacher-parent & 10 & Gossip & 19 \\
& Administrator-parent & 4 & Verbal criticism & 10 \\
\multirow{3}{*}{ Horizontal } & Teacher-teacher & 16 & Shouting & 2 \\
& Administrator-administrator & 12 & & \\
& Coterie-Coterie & 6 & & \\
\hline
\end{tabular}


As shown in Table 3, the levels of conflict in school occur vertically between administrator and teacher $(\mathrm{f}=21)$, teacher and parent $(\mathrm{f}=10)$, administrator and parent $(\mathrm{f}=4)$ whereas occurring horizontally between teacher and teacher $(\mathrm{f}=16)$, administrator and administrator $(\mathrm{f}=12)$, and between group teachers $(\mathrm{f}=6)$. It has also emerged that conflicts occur as argument $(\mathrm{f}=26)$, gossip $(\mathrm{f}=19)$, verbal criticism $(\mathrm{f}=10)$ and shouting $(\mathrm{f}=2)$.

Some of the views of teachers on the level and type of the conflicts at schools are presented below in direct quotes:

"There may be conflicts between administrators, administrator and teacher, teacher and teacher. Conflicts can usually be arguments. Sometimes it can be sustained unilaterally in the condition of silence of one side." (T19),"It may occur in the meetings between teachers, teachers and administrators, or group teachers who work for the same class. Conflicts break out as arguments, but sometimes they can also occur as shouting." (T13),"It can take place as verbal criticism or arguments between administration and teachers." (T21).

The views of teachers on the negative effects/results of the conflicts at schools are shown in Table 4.

Table 4. Negative effects/results of conflicts

\begin{tabular}{|c|c|c|}
\hline Theme & Code & f \\
\hline \multirow{15}{*}{ Individual Effects } & Weariness and fatigue & 17 \\
\hline & Burnout & 15 \\
\hline & Reluctance to do work & 14 \\
\hline & Reduced productivity and performance & 13 \\
\hline & Decreased organizational commitment & 13 \\
\hline & Stress and anxiety & 12 \\
\hline & Isolation & 10 \\
\hline & Unhappiness & 9 \\
\hline & Cynicism & 9 \\
\hline & Decrease in motivation & 8 \\
\hline & Reluctance to come to the school & 7 \\
\hline & Desire to get away from the school & 6 \\
\hline & Ethical behaviors starting to disappear & 4 \\
\hline & Retreat & 3 \\
\hline & Anger & 2 \\
\hline \multirow{9}{*}{$\begin{array}{l}\text { Interpersonal } \\
\text { Effects }\end{array}$} & Difficulty in communicating & 12 \\
\hline & Not wanting to share the same environment & 11 \\
\hline & Reserved behaviors & 9 \\
\hline & Reluctance to chat & 8 \\
\hline & Unwillingness to attend common facilities & 7 \\
\hline & Adopting a particular attitude & 6 \\
\hline & Prejudices & 5 \\
\hline & Misunderstandings & 4 \\
\hline & Distrust to others & 2 \\
\hline \multirow{6}{*}{$\begin{array}{l}\text { Organizational } \\
\text { Effects }\end{array}$} & Decrease in productivity in educational facilities & 17 \\
\hline & Emergence of negative behaviors such as gossip, favoritism & 15 \\
\hline & Emergence of groupings & 12 \\
\hline & Reduced collaboration and teamwork & 10 \\
\hline & Deterioration of the school atmosphere & 9 \\
\hline & The authoritarianism of school administration & 5 \\
\hline
\end{tabular}

As shown in Table 4, it emerged that the negative effects/results of conflicts in schools were collected under individual, interpersonal and organizational effects. Individual effects of conflicts include weariness and fatigue $(\mathrm{f}=17)$, burnout $(\mathrm{f}=15)$, reluctance to do work $(\mathrm{f}=14)$, 
reduced productivity and performance $(\mathrm{f}=13)$, decreased organizational commitment $(\mathrm{f}=13)$, stress and anxiety ( $\mathrm{f}=12)$, isolation ( $\mathrm{f}=10)$, unhappiness $(\mathrm{f}=9)$, cynicism ( $\mathrm{f}=9)$, decrease in motivation $(\mathrm{f}=8)$, reluctance to come to the school $(\mathrm{f}=7)$, desire to get away from the school $(\mathrm{f}=6)$, ethical behaviors starting to disappear $(\mathrm{f}=4)$, retreat $(\mathrm{f}=3)$ and anger $(\mathrm{f}=2)$. Moreover, interpersonal effects emerge as difficulty in communicating $(\mathrm{f}=12)$, not wanting to share the same environment $(f=11)$, reserved behaviors $(f=9)$, reluctance to chat $(f=8)$, unwillingness to attend common facilities ( $\mathrm{f}=7$ ), adopting a particular attitude $(\mathrm{f}=6)$, prejudices $(\mathrm{f}=5)$, misunderstandings $(\mathrm{f}=4)$ and distrust to others $(\mathrm{f}=2)$; Lastly, organizational effects were found to be decrease in productivity in educational facilities $(\mathrm{f}=17)$, emergence of negative behaviors such as gossip, favoritism $(f=15)$ emergence of groupings $(f=12)$, reduced collaboration and teamwork $(\mathrm{f}=10)$, deterioration of school atmosphere $(\mathrm{f}=9)$, the authoritarianism of school administration $(\mathrm{f}=5)$.

Some of the views of teachers on the negative effects/results of the conflicts at schools are presented below in direct quotes:

"The conflict affects our entire school. A tense atmosphere comes into being. The groupings break out." (T12) "It affects communication between individuals negatively. Disruptive behaviors can start in respect for school atmosphere. Negative behaviors such as gossip may appear." (T10), "Individuals can be more distant from each other. Most of the time, they don't want to come to you, and they don't want to be in the same environment as you." (T25), "Groupings can appear. People who have conflicts can get isolated. Cooperation decreases, and employees' motivation may decrease." (T23), "Conflicts can cause weariness and fatigue. I can become reluctant for doing my job. When I have conflict, my performance decreases." (T21), "... I don't want to come to the school when I have conflicts. I want to get away from the school." (T17).

The views of teachers on the positive effects/results of the conflicts at schools are shown in Table 5.

Table 5. Positive effects/results of conflicts

\begin{tabular}{lll}
\hline Themes & Participants' Views & f \\
\hline & Increase in productivity & 7 \\
& Resolving misunderstandings & 5 \\
& Acknowledging different views & 5 \\
\multirow{3}{*}{ Individual Effects } & Learning to listen & 4 \\
& Learning to respect different thoughts & 3 \\
& Ending of resentment and tension between the parties & 2 \\
& Gaining a different perspective & 1 \\
& Learning the communication styles of each other & 1 \\
\hline & The emergence of new ideas & 10 \\
& Development of leadership roles & 7 \\
& Increased school dynamism & 5 \\
& Achieving the best ideas & 3 \\
& Increased democratization & 2 \\
& Detailed consultation of events or situations & 1 \\
\hline
\end{tabular}

As illustrated in Table 5, it emerged that the positive effects of the conflicts in schools were collected under two themes as individual and organizational. Individual effects include increase in productivity $(\mathrm{f}=7)$, resolving misunderstandings $(\mathrm{f}=5)$, acknowledging different views $(\mathrm{f}=5)$, learning to listen $(\mathrm{f}=4)$ learning to respect different thoughts $(\mathrm{f}=3)$, ending of resentment and tension between the parties $(\mathrm{f}=2)$, gaining a different perspective $(\mathrm{f}=1)$, learning the communication styles of each other $(\mathrm{f}=1)$ whereas organizational effects emerge 
as the emergence of new ideas ( $\mathrm{f}=10)$, development of leadership roles $(\mathrm{f}=7)$, increased school dynamism ( $\mathrm{f}=5)$, achieving the best ideas $(\mathrm{f}=3)$, increased democratization $(\mathrm{f}=2)$, detailed consultation of events or situations $(\mathrm{f}=1)$.

Some of the views of teachers on the positive effects/results of the conflicts at schools are presented below in direct quotes:

"Conflicts increase the productivity of individuals." (T20), "People realize that there are also different opinions. Tension and resentment between the parties may come to an end. " (T1), "It occurs that individuals may have different opinions. We also learn the way people communicate." (T9), "If the conflicts within the cultural structure of the school are positive and constructive, school dynamism can increase. The leadership roles of individuals can also improve in conflict management. " (T19), "In addition to revealing disagreements, conflicts can give individuals different perspectives by ensuring respect for those who think differently. I also think that mild conflicts are beneficial in favor of democratization. " (T17), "It can resolve misunderstandings. It appears that everyone might have a different opinion. Therefore, I think conflicts are beneficial." (T10).

The views of teachers on the methods used in the resolution and management of conflicts at schools are shown in Table 6.

Table 6. Methods used in the resolution and management of conflicts

\begin{tabular}{lll}
\hline Theme & Codes & f \\
\hline & Silence of one part & 21 \\
& Distancing & 18 \\
& Mutual silence of the parties & 17 \\
& Retreating-giving up the conflict & 10 \\
Individual Methods & Being respectful and tolerant & 4 \\
& Compromising of one of the parties & 3 \\
& Being solution-oriented & 2 \\
& Talking & 1 \\
\hline & Calming and trying to convince the parties & 20 \\
Administrative & Ignoring and being indifferent & 15 \\
Methods & Pretending it never happened & 11 \\
& Achieving consensus & 8 \\
& Listening & 7 \\
& Silencing using authority & 5 \\
& Being solution-oriented & 2 \\
\hline
\end{tabular}

As presented in Table 6, it emerged that the methods for the resolution and management of conflicts in schools were grouped into two different themes, individually and administratively. The individual methods used to resolve conflicts have been identified as silence of one part $(f=21)$, alienation $(f=18)$, mutual silence of the parties $(f=17)$, retreatinggiving up the conflict $(\mathrm{f}=10)$, being respectful and tolerant $(\mathrm{f}=4)$, compromising one of the parties $(f=3)$, being solution-oriented $(f=2)$ and talking $(f=1)$. As for the administrative methods, calming and trying to convince parties $(\mathrm{f}=20)$, ignoring and being indifferent $(\mathrm{f}=15)$, pretending it never happened ( $\mathrm{f}=11$ ), achieving consensus ( $\mathrm{f}=8)$, listening $(\mathrm{f}=7)$, silencing using authority $(\mathrm{f}=5)$, being solution-oriented $(\mathrm{f}=2)$, contacting the mediator (arbitrator) $(\mathrm{f}=1)$ are preferred.

Some of the views of teachers on the methods used in the resolution and management of conflicts are presented below in direct quotes: 
"I'm moving away from the conflict, so the conflict is terminated, albeit temporarily." (T14), "School administrators might use their legal authority to resolve conflicts. They might try to suppress the teachers by starting the conversation like 'I, as the headmaster,..." There was a conflict among friends at the school where I used to work. Our headmaster applied to the arbitrator and resolved the conflict." (T7), "Our headmaster always tries to calm and convince the parties. I've never seen he's used any other methods. " (T19), "The conflicts are tried to be resolved by reaching a mutual consensus. In parent-teacher relations, conflicts are also tried to be resolved by consulting the school administration." (T26), "When conflict occurs, the parties may prevent the conflict from prolonging by being indifferent" (T29), "...Ignoring the person you're in conflict with is a solution. Of course, the healthiest solution is to be open to communication. Sometimes, the conflict can be ended by mediators." (T1).

\section{Results, Discussion and Recommendations}

According to the results of the study, the causes of conflicts in schools are grouped as individual, interpersonal, administrative and other factors. Individual factors include prejudice, personality differences, low motivation, being manipulative, not being honest and sincere and unwilling to learning. The causes of conflicts arising from interpersonal relationships are determined as negative communication, groupings, not recognizing the newcomers, the ambition of success in teachers, not welcoming criticism, jealousy of success and qualifications of others, the desire of individuals to be at the forefront all the time, gossip and rumor, having different ideas, misunderstanding, false and incriminating accusations of individuals, not being respectful to others' opinions, avoiding work and the presence of teacher with professional inexperience. As for the administrative factors; poor leadership skills, lack of proficiency in the field of educational administration, favoritism, the desire to be obeyed by all means, dominating behavior, not accepting intervention, neglecting the teachers' thoughts, adopting an autocratic and refraining management, not fulfilling duties and responsibilities and tending to advocate some teachers individually were found to cause conflicts. Finally, other reasons that cause conflicts emerged as giving the workload to the certain employees, insufficient resources, not fulfilling duties and responsibilities by teachers, power discrepancy between administrators and teachers, the presence of teachers with different years of experience. Educational institutions have a structure that focuses on working together in harmony and cooperation. However, there is no such thing as every individual shall be happy all the time. For this reason, conflict is an inevitable phenomenon in educational institutions (Şentürk, 2006). Communication problems in schools, organizational structure, personality and human factor and limited resources are the sources of conflict (Arslan, 2020). In his study, Bayar (2015) determined that the size of the organization, communication barriers, lack of resources, lack of common values and opinions, differences in the way of management, individual differences among personnel and differences in status and roles caused conflict. There are conflicts in schools due to the lack of effective use of communication channels, the lack of timely announcement of important information to teachers, inadequate communication channels used by administrators, different personal characteristics of teachers, different cultural structures and the lack of appropriate distribution of work within the school (Erdoğan, 2002). Baykal and Kovanc1 (2008) stated in their studies that the factors that cause conflict are separated as individual and organizational, and that organizational structure and working area, differences in the individual characteristics of administrators and employees may cause conflict. Different practices of administrators who do not have the necessary organizational skills and knowledge also cause conflict in the organization (Koçel, 2005). In general, it is seen that the results of this research coincide with the related literature. 
According to the study results, the factors ensuring no conflicts in schools where there is no conflict are determined as effective communication, fulfilling everyone's duties and responsibilities on time, organizational harmony, not objecting to the given task, small number of employees, teachers and administrators acting in accordance with the rules of professional ethics and work ethics, ensuring sustainability in professional development through cooperation and teamwork. It is very important to use communication functionally in schools where human relations are intense. Positive and effective communication between administrators, teachers and parents will prevent the appearance of conflicts. However, considering the positive results of the conflict, having no conflicts can make the school static. In the 21 st century, when change and development are rapid, the desired level of conflict in schools which enables the emergence of change, development and new ideas can contribute to the development of the school. As a matter of fact, Rahim (2002) stated that moderate conflicts will contribute positively to the organization, that it prepares an environment for different ideas to emerge within the organization and for people to express themselves comfortably. Yet, in case of moderate conflicts, it must be in such a way that it will not exceed the power of the administrator in order to provide the administrator with good experience and positive contribution. The functionality of communication among students, teachers, administrators, parents and other staff will make it easier for the school to achieve its objectives by ensuring that the facilities carried out are effective and efficient. In addition to communication, considering that many of the facilities carried out in schools require teamwork and cooperation (Ertürk \& Argon, 2019), collaborating in teamwork will contribute to organizational harmony by increasing the interaction among teachers, administrators and parents. Likewise, as the number of staff and students in schools increases, problems will increase inevitably. Therefore, it is highly possible that conflicts do not occur that freqyently in schools with low staff numbers. However, as mentioned above, a moderate conflict will ensure that the school is dynamic and new ideas emerge. Teachers and administrators are widely expected to comply with the rules of professional ethics in schools as the compliance with ethical rules in schools that enable the progress and development of society and educate future generations will contribute to the upbringing of students as desired . For this reason, it can be deemed as a positive situation that conflict does not occur among administrators, teachers, parents and students who behave in accordance with professional ethics and rules.

Conflicts occur vertically between administrator-teacher, teacher-parent and administratorparent whereas it takes place at a horizontal level between teacher-teacher, administratoradministrator and among coteries. The conflicts take place in the way of argument, gossip, verbal criticism and shouting. Schools are among the institutions where the human factor exists in the most effective way. Conflicts are a natural consequence of the spiral of administrator-teacher-student-parent (Arslan, 2020). In schools where such an intense interaction exists, related vertical and horizontal conflicts are normal. Low-level conflicts show that some things are not ventured in the organization and that it is not open to change and development whereas high-level conflicts lead to reduced organizational efficiency and bringing objectives to the background by making the administrators and employees spend their times on conflict (Rahim, 2002). According to the behavioral and traditional approach, conflict has negative consequences and reduces the organizational efficiency. Therefore, conflict has been described as a situation that needs to be eliminated. According to the modern conflict approach, what matters is the level of conflict. It is desirable that conflicts serve the goals of the organization. A desired level of conflict will contribute to the development of the organization. (Rahim, 2002; Karip, 2000). Therefore, it may be a positive situation that there is no conflict in schools according to the behavioral and traditional approach. However, from the point of view of the modern approach, moderate conflicts serve 
for the effectiveness and efficiency of schools in a good sense. As a matter of fact, considering the results of this research, it was revealed that the conflict had positive effects and results.

According to the findings, conflicts lead to individual, interpersonal and organizational negative effects and consequences. Weariness and fatigue, burnout, reluctance to do work, reduced productivity and performance, decreased organizational commitment, stress and anxiety, isolation, unhappiness, cynicism, decrease in motivation, reluctance to come to the school, desire to get away from the school, ethical behaviors' starting to disappear, retreat and anger are the individual negative effects of conflicts. Considering this, it can be said that administrators and teachers have a very difficult time contributing to the development of the school because of the conflict since burnout leads to lateness for work, getting medical reports more frequently, unwillingness for innovation and creativity (Güneş, Bayraktaroğlu, \& Kutanis, 2009); reluctance to work leads to reduced productivity, performance and quality of education; decrease in organizational commitment causes decreased job satisfaction, motivation, participation and desire to stay in the organization and increase in lateness, retreat and absence (Balay, 2000); stress damages the mental health of individuals and can negatively affect the atmosphere in the workplace (Iş1khan, 2004). Isolation, which is one of the negative consequences of conflict, causes the individual to have reduced job satisfaction, increased stress level, decreased productivity and demonstrate an aggressive, introverted and unconfident profile with reduced sense of self (Karaduman, 2013). The lack of motivation of teachers decreases their effectiveness and efficiency in educational facilities, reduce their performance and cause them to enter the classroom reluctantly. In this context, in schools, which are educational organizations, it is important for teachers to have positive impressions towards the school so that the atmosphere of the school can be positive (Gürcüoğlu \& Uyar, 2020). As a result, it is clear that it will be difficult for school stakeholders who experience these problems to contribute to improve the education quality of the school.

Difficulty in communicating, not wanting to share the same environment, reserved behaviors, reluctance to chat, unwilling to attend the common facilities, adopting a particular attitude, prejudices, misunderstandings and distrust are the negative interpersonal effects of conflict. Since schools are the organizations with the most intense human relations, the emergence of communication difficulties will disrupt the activities that should be carried out in the school. As it is necessary to carry out the school facilities in cooperation and teamwork, the situation in which the teachers want to get away from each other, act distantly, and do not want to talk will negatively affect the discipline and atmosphere, and prevent the students and the school from succeeding.

The negative organizational effects of conflicts are determined as decrease in productivity in educational facilities, gossip, favoritism, groupings, reduced collaboration and teamwork, deterioration of school climate and the authoritarianism of school administration. The deterioration of the school atmosphere may adversely affect the organizational commitment, job satisfaction, intra-organizational communication, motivation and performance of the employees, and result in a decrease in productivity in the organization. Such a situation which will prevent the organization from achieving its objectives may have such serious consequences as the perishing of the organization (Halis \& Uğurlu, 2008). Achieving objectives, solving problems, implementing change and innovation, improving educational facilities and achieving the desired efficiency is possible with effective teamwork that requires cooperation between teachers at schools that will provide social change (Ertürk \& Argon, 2019). Therefore, the fact that the conflicts negatively affect the teamwork that 
requires cooperation and collaboration will cause many facilities to fail or even be terminated. Falling productivity in educational facilities can be interpreted as a decrease in the success of students and schools, which can also mean the deviation from the objectives. Gossip can lead to reduced work efficiency, failure of teamwork, low morale and insecurity, the start of unrest in the organization, loss of reputation and groupings (Arabac1, Sünkür, \& Şimsek, 2012; Bacaksız \& Yıldırım, 2015). Şimsek and Çelik (2008) stated in their studies that individuals experiencing a conflict have negative situations such as blood pressure, irritability, anger and stress, and that the perception of being in a state of failure can lead them to feel bad and exhibit hostile attitudes. For this reason, conflict can lead to lower levels of motivation and satisfaction of employees, decreased productivity and organizational commitment, and even increased absenteeism. Köz (2016) stated in his study that conflict leads to deviation from organizational objectives, increased loss of labor, time and finance, spending energy on other works instead of important ones, low morale and motivation, dismissal and deterioration of cooperation. In general, it is seen that the results of this study are in the same line with the related literature.

The positive effects and results of conflicts in schools occur individually and organizationally. Positive individual effects emerge as increase in productivity, resolving misunderstandings, realizing different ideas, learning to listen, learning to respect different thoughts, ending of resentment and tension between the parties, gaining a different perspective, learning the communication styles of each other whereas positive organizational effects are the emergence of new ideas, development of leadership roles, increased school dynamism, achieving the best ideas, increased democratization, detailed consultation of events or situations. Genç (2005) stated that the problems that exist but are hidden are exposed through conflict; and these problems can be discussed, organizational communication develops, and original ideas emerge. Karip (2000) said that the conflict constitutes a climate in which relations are better, that it allows employees to listen to each other's thoughts, contributes to the development of respect for themselves and for each other, increases and accelerates the individual development, thus making the employees more effective and efficient, identify the elements that prevent the organization from being effective and produce better solutions to problems, have a more harmonious working environment in the organization and the decrease of organizational monotony, ensure to make things more fun and contribute to organizational change. When well-managed, the conflict assist in that relationships among employees are based on solid foundations. It provides psychological maturity to employees, contributes to the effective resolution of problems in the organization by noticing them (Y1ldırım, 2005), encourages creative thinking, increases the research trends of employees, ensures clear expression of ideas in the organization, and increase the motivation levels of employees (Gülşen \& Gökyer, 2012). The positive or negative effects of conflicts in schools are directly related to how the school administrator manages the conflict. Well-managed conflicts allow the school to thrive and minimize the downsides of non-functional conflicts (Yiğit, 2015). Therefore, school administrators have great duties to turn the conflict into an opportunity and make it positive for the school. Surely, the fact that teachers and parents have knowledge of conflict management along with the administrators can make the process better managed and result in better outcomes. Thereby, a negative approach to conflict can cause monotony for schools. School administrators and teachers should see the conflict as an opportunity for the school's development.

In the resolution and management of conflicts in schools, individual methods such as silence of one part, distancing, mutual silence of the parties, retreating-giving up the conflict, being respectful and tolerant, compromising of one of the parties, being solution-oriented and 
talking are used as well as administrative methods such as calming and trying to convince the parties, ignoring and being indifferent, pretending it never happened, achieving consensus, listening, silencing using authority being solution-oriented and contacting the mediator (arbitrator). It can be interpreted as the inability of school administrators to try to manage the conflict mostly with the methods of calming and trying to convince them and ignoring or being indifference to conflict. For good conflict management, it is required to know the organizational management and its theories because structural theories in the resolution of conflict suggest an authoritarian tendency whereas administrative theories propose methods such as resorting to use force, using administrative power and negotiation. While behavioral theories argue that the parties should coexist and communicate face-to-face, system theories state that common values should be established for conflicting parties, and that it could be resolved by the parties talking to each other. The contingency theory, on the other hand, states that in the conflict management, the conditions of the parties should be fully analyzed, that there is no best and only way of conflict management, that the appropriate and applicable method can be implemented according to the conditions (Owens, 1998, in Yiğit, 2003). Therefore, the ability of school administrators to attain a positive result of the conflict by knowing these theories well can contribute to school, teachers and students. Otherwise, conflicts can either take place at a high level, harming the school and stakeholders, or stay at a mild level, preventing organizational problems. For this reason, all school stakeholders, especially school administrators, need to have background knowledge about the conflict. Karip (2000) and Üngüren (2008) stated that in order to overcome the conflicts occurring in a school, strategies such as avoidance, compromise, reconciliation, coercion and integration, cooperation should be used. Sertok (2006) indicated that school administrators use the styles of integration, compliance, compromise, domination and avoidance in conflict resolution frequent use of integration, compliance and reconciliation; occasionally resort to dominating and avoiding. Teachers, on the other hand, determined that school administrators use domination, integration, compliance and compromise styles frequently and the avoidance style occasionally. Vaiz (2017) found that the mostly used strategies in conflict management are domination, integration and avoidance. Bayar (2015) found in his study that school administrators mostly use avoidance, compliance and obedience, compromise, coercion and negotiation strategies to eliminate conflicts. Instead of facing conflict, developing solutions to problems and managing conflicts in a way that benefits for organization and employees, it is often possible to avoid and suppress the problems led by conflict or to try to solve the problems using authoritarian methods (Karcioğlu \& Alioğulları, 2012). Instead of ignoring the conflicts that occur in school, managing these conflicts constructively should become one of the main tasks of teachers (Arslan, 2020). Given the diversity and inevitability of causes of conflict in schools, it is understood that the important thing is to minimize conflict and manage it in the most effective way. It should be remembered that trying to eliminate or ignore all causes of conflict will hinder the development of the school (Yiğit, 2015). Therefore, when a conflict is well managed, it will ensure that the school is more effective and efficient, rather than harming the school and employees.

As a result, with this research, conflict has been examined in a general spectrum, enabling practitioners and researchers to see the causes, level and form of conflict, its effects, the methods used in the resolution and management of conflicts, and the reasons why there is no conflict in schools where there is no conflict. Because there is no study that addresses the conflict in such a wide range in the literature. Especially in the research, revealing the factors that provide this situation in schools where there is no conflict contributes to the originality of the research. A medium-level conflict in schools will result in positive results in terms of individual and organizational aspects and therefore increase the effectiveness of schools when 
considering the positive effects and consequences of conflicts in schools. However, since the increase in the level of conflict can lead to negative individual, interpersonal and organizational outcomes, both teachers and school administrators at schools should have a broad knowledge of conflict and good conflict management skills. In addition, conflict information will minimize the individual, interpersonal and administrative reasons that reveal the conflict.

In line with the results of the research, the following recommendations were developed:

- The proficiency of school administrators in the field of educational administration should be increased. Therefore, it may be good to charge one of candidates who have the proficiency of educational administration as administrator.

- Taking the causes of conflict into account, school administrators and teachers should participate in seminars and courses on communication, interpersonal relations, conflict management and resolution.

- Administrators and teachers need to be more sensitive about work ethics and get training in these subjects.

- Important duties and responsibilities fall on school administrators particularly in the positive outcome of the conflicts in schools. Therefore, school administrators should be able to turn conflict into an opportunity for the school and make the school more effective and efficient by putting forward good conflict management.

- All school stakeholders should participate in seminars, courses and workshops on conflict to minimize the individual, interpersonal and organizational negative effects of conflicts in schools.

- Conflicts should be taken as an opportunity for schools to adapt to change and innovations and to solve problems.

- School administrators' views on conflict can be investigated by conducting another qualitative research.

\section{Limitations of the Study}

This research; It is limited to the answers given to the research questions by 40 teachers from 3 primary schools, 2 secondary schools and 2 high schools in Yeniçağa district of Bolu.

\section{References}

Akgöz, E. E., \& Cemaloğlu, N. (2020). Ortaokullarda çatışma nedenleri ve çözümüne ilişkin yönetici ve ögretmen görüşleri [Views of administrators and teachers on conflict causes and resolution in secondary schools]. The Journal of International Education Science, 22(7), 60-84, doi: 10.29228/INESJOURNAL.41497.

Arabac1, B. İ., Sünkür, M., \& Şimşek, F. Z. (2012). Teachers’ views regarding gossip and rumour mechanism: A qualitative study. Educational Administration: Theory and Practice, 18(2), 171-190.

Arslan, G. (2020). Okul yöneticileri ve öğretmenlerin çatışma yönetimine ilişkin algıları [Perceptions on conflict management of school administrators and teachers]. (Master's thesis). Eskişehir Osmangazi University Institute of Educational Sciences, Eskişehir. 
Bacaksız, F. E., \& Yıldırım, A. (2015). Gossip and rumors: The situation in hospitals and attitudes of nurses. Journal of Health and Nursing Management, 2(3), 113-120.

Baki, A., \& Gökçek, T. (2012). Karma yöntem araştırmalarına genel bir bakış [A general overview of mixed method researches]. Electronic Journal of Social Sciences, 11(12), $1-21$.

Balay, R. (2000). Yönetici ve ögretmenlerde örgütsel bağlllık [Organizational commitment in administrators and teachers]. Ankara: Nobel Publishing.

Bayar, A. (2015). Bir örgüt olarak okulda meydana gelen çatışma nedenleri ve çözüm yollarına yönelik okul müdürlerinin görüşleri [The reasons of conflicts in school as an organization and finding some potential solutions in terms of school principals' perspective]. Sakarya University Journal of Education, 5(3), 130-141.

Baykal, K., \& Kovancı, A. (2008). Yönetici ve astlar arasındaki anlaşmazlıkların çözümüne yönelik bir araştırma [A research on solving of the conflict between the managers and the workers]. Journal of Aviation and Space Technologies, 3(3), 21-38.

Büyüköztürk Ş., Kılıç-Çakmak, E., Akgün, Ö. E., Karadeniz, Ş., \& Demirel, F. (2012). Bilimsel araştırma yöntemleri [Scientific research methods]. Ankara: Pegem Publishing.

Corvette, B. A. B. (2007). Conflict management: A practical guide to developing negotiation strategies. New Jersey: Prentice Hall.

Creswell, J. W. (2007). Qualitative inquiry and research design-choosing among five approaches. Thousand Oaks, California: SAGE Publications.

Demirdağ, S. (2016). İlkokul yöneticilerinin etik liderlik davranışları ile çatışma yönetimi stratejileri arasındaki ilişki: ücretli ögretmen görüşleri [The relationship between primary school administrators' ethical leadership and conflict management strategies: The perceptions of substitute teachers]. TURKISH STUDIESInternational Periodical for the Languages, Literature and History of Turkish or Turkic, 11(3), 879-894. doi: 10.7827/TurkishStudies.9250.

Demirkaya, Y. (2012). Okul müdürlerinin çatışma yönetim stratejileri ve iletişim tarzlarına yönelik ögretmen alglları [Teacher perceptions of school principals' conflict management strategies and communication styles]. (Master's thesis). Mehmet Akif Ersoy University Institute of Educational Sciences, Burdur.

Erdoğan, İ. (2002). Okul yönetimi ve ögretim liderliği [School management and teaching leadership]. Istanbul: Sistem Publishing.

Eren, E. (2008). Örgütsel davranış ve yönetim psikolojisi [Organizational behavior and management psychology]. Istanbul: Beta Publishing.

Ertürk, R. (2019, April). Okullarda çatışma ve etkileri [Conflict and its effects in schools]. Paper presented at 28th Educational Sciences Congress, Hacettepe University, Ankara. Abstract retrieved from http://www.ices-uebk.org/downloads/icesozet.pdf

Ertürk, R. ve Argon, T. (2019, April). Öğretmen görüşlerine göre okullarda takım çalışmalart ve sosyal kaytarma [According to the teacher teamwork and social copout in schools]. 28th International Educational Sciences Congress Full Text Book (pp. 491-514). Full Text retrieved from http://www.icesuebk.org/downloads/icestammetin.pdf

Fabunimi, M., \& Alimba, C. N. (2010). Conflict in school climate: A synopsis of its nature, causes, effects and management approaches. African Journal of Education Al Management, 13(2), 205-226.

Genç, N. (2005). Yönetim ve organizasyon [Management and organization]. Ankara: Seçkin Publishing.

Gülşen, C., \& Gökyer, N. (2012). Türk Ĕ̈itim sistemi ve okul yönetimi [Turkish Education System and school management] Ankara: Anı Publishing. 
Güneş, İ., Bayraktaroğlu, S., \& Kutanis, R. Ö. (2009). A relationship on organizational commitment of emploless and burnout level: Sample from a state university. Suleyman Demirel University The Journal of Faculty of Economics, 3, 481-497.

Gürcüoğlu, S., \& Uyar, M. (2020). Examining the relationship between organizational conflict and organizational climate from the perspective of secondary education teachers. Balıkesir University The Journal of Social Sciences Institute, 23(43), 229254.

Halis, M., \& Uğurlu. Ö. Y. (2008). Organizational climate in the light of current studies. ISGUC The Journal of Industrial Relations and Human Resources, 10(2), 101-123.

Işıkhan, V. (2004). Çalışma hayatında stres ve başa çıkma yolları [Stress and ways to cope in working life]. Ankara: Sandal Publishing.

İpek, C. (2003). Örgütsel çatışma ve çatışma yönetiminde uygulanabilecek örgüt geliştirme aracıları içinde [Organizational development agents that can be applied in organizational conflict and conflict management in], C. Elma \& K. Demir (Ed.), Yönetimde çağdaş yaklaşımlar [Contemporary approaches in management], (pp. 219242). Ankara: An1 Publishing.

Karaduman, M. (2013). İş yaşamında yalnızlık algısının örgütsel vatandaşlık davranışı ile ilişkisi ve ögretmenler üzerinde bir uygulama [Relationship of loneliness perception in business life with organizational citizenship behavior and an application on teachers]. (Master thesis). Uludağ University Institute of Social Sciences, Bursa.

Karcioğlu, F., \& Alioğulları, Z. D. (2012). Relationship between causes of conflict and conflict management styles. Ataturk University Journal of Economic and Administrative Sciences, 26(3-4), 215-237.

Karip, E. (2000). Çatışma yönetimi [Conflict management]. Ankara: Pegem Publishing.

Koçak, S. (2012). Öğretmenler arası çatışmalar ile okul müdürü-öğretmen çatışmalarında kullanılan yöntemlerin ve etkililik düzeylerinin karşılaştırılması: Uşak ili örneği [Comparison of the methods and their effectiveness levels used at between teachers and administrator-teacher conflicts: Example of Uşak province]. (Master's thesis). Hacettepe University Institute of Social Sciences, Ankara.

Koçel, T. (2005). Işletme yöneticiliği [Business management]. Istanbul: Arıkan Publishing.

Konak, M., \& Erdem, M. (2015). Öğretmenlerin görüşlerine göre ilkokul yöneticilerinin etik liderlik davranışları ile çatışma yönetme stratejileri arasındaki ilişki [According to the teachers' opinions the relationship between the ethical leadership behaviors of the elementary school principals and their conflict management strategies]. Educational Administration in Theory and Practice, 21(1), 69-91.

Köz, K. (2016). Eğitim yöneticilerinin çatışma yönetimine bakış açıları ve çatışma yönetim stratejileri [The perspectïve of training managers on conflict management and conflict management strategies]. (Master's thesis). Bahçeşehir University Institute of Educational Sciences, Istanbul.

Kurt, E. (2019). Illkokul yöneticileri ile ögretmenler arasında yaşanan çatışmalar ve yöneticilerin uyguladıkları çözüm yolları [Conflicts betwwen primary school adminatrators and teachers, and the ways used by administrators for solutions]. (Master's thesis). Maltepe University Institute of Social Sciences, Istanbul.

Leung, A. (2008). Interpersonal conflict and resolution strategies: an examination of hong kong employees. Team Performance Management, 3(4), 165-178.

Moisoglou, I., Prezerakis, P., Galanis, P., Siskou, O., Maniadakis, N., \& Dafni, K. (2014). Conflict management in a greek public hospital: collaboration or avoidance. International Journal of Caring Sciences, 7, 75-82.

Msila, V. (2012). Conflict management and school leadership. Journal of Communication, $3(1), 25-34$. 
Okotoni, O., \& Okotoni, A. (2003). Conflict management in secondary schools in Osun State, Nigeria. Nordic Journal of African Studies 12(1), 23-38.

Öner-Körüklü, N. (2010). Kişiler arast ilişkiler ve etkili iletişim [Interpersonal relationships and effective communication]. Ankara: Pegem Publishing.

Özdemir, N. (2018). Okullarda öğretmenlerin yaşadığı çatışma ve çatışma yönetim stilleri [Conflict and conflict management styles of teachers in schools]. Sivas Cumhuriyet University Faculty of Letters Journal of Social Sciences, 42(2), 93- 116.

Pickering, S. (2016). Introducing spatialgridbuilder: A new system for creating geo-coded datasets. Conflict Management and Peace Science, 33(4), 423-447. doi:10.1177/0738894215581320.

Rahim, M. A. (2002). Toward a theory of managing organizational conflict. The International Journal of Conflict Management. 13(3), 206-235.

Rabionet, S. E. (2011). How i learned to design and conduct semi-structured interviews: An ongoing and continuous journey. Qualitative Report, 16(2), 563-566. doi: $10.46743 / 2160-3715 / 2009.2850$.

Sarpkaya, D. (2002). Conflict management in educational organizations: A case study. Educational Administration: Theory and Practice, 31(31), 414-429.

Sertok, S. (2006). Illköğretim okulları müdürlerinin kendilerinin taraf olmadıkları çatışmaları yönetme tarzlarl [Primary school principals' style of managing conflicts in which they are not a party]. (Master's thesis). Yeditepe University Institute of Social Sciences, Istanbul.

Şentürk, N. (2006). Illköğretim okullarında yaşanan çatışma türleri ve yöneticilerin izledikleri çözüm yöntemleri [The conflicts encountered in primary education schools and the solution strategies school administrators apply]. (Master's thesis). Trakya University Institute of Social Sciences, Edirne.

Şimşek, M. Ş., \& Çelik, A. (2008). Çă̆daş yönetim ve örgütsel başarım. [Contemporary management and organizational success]. Konya: Education Bookstore Publications.

Şimşek, N. (2019). Illkokul ve ortaokul yöneticilerinin çatışma çözme stilleri hakkında ögretmen görüşleri [Teachers'ideas about conflict resolution methods of primary and secondary schools'manager]. (Master thesis). İstanbul Okan University Institute of Social Sciences, Istanbul.

Teddlie, C., \& Tashakkori, A. (2015). Karma yöntem araştırmalarının temelleri [Fundamentals of mixed method research]. (Y. Dede \& S. B. Demir Trans. Ed.), Ankara: Anı Publishing.

Uchendu, C.C., Anijaobi-Idem, F. N., \& Odigwe, F. N. (2013). Conflict management and organisational performance in secondary schools in cross river state, Nigeria. Research Journal in Organizational Psychology \& Educational Studies 2(2), 67-71.

Üngüren, E. (2008). Organization conflict management: A research on hospitality industry. The Journal of International Social Research, 1(5), 880-909.

Weitten, W., Yost-Hammer, E., \& Dunn, D. S. (2016). Psychology and contemporary life. (E. İkiz, Trans. Ed.), Ankara: Nobel Publishing.

Vaiz, M. E. (2017). İlköğretim okullarında çatışma durumlarının yönetilmesine ilişkin ögretmen ve yönetici görüşleri [Teacher and administrator views regarding the management of conflict situations in primary schools]. ( $\mathrm{PhD}$ dissertation). Yak1n Doğu University Institute of Educational Sciences, Lefkoşa.

Yıldırım, A. (2005). Empati ve çatışmalar [Empathy and conflicts]. Ankara: Yarg1 Publishing.

Yıldırım, A., \& Şimşek, H. (2015). Sosyal bilimlerde nitel araştırma yöntemleri [Qualitative research methods in social sciences]. Ankara: Seçkin Publishing. 
Yiğit, İ. (2015). Ortaöğretim yöneticilerinin çatışma yönetimi stilleri [Conflict management styles of secondary school administrators]. (Master's thesis). Okan University Institute of Social Sciences, Trabzon.

Yin, R. K. (2003). Case study research: Design and methods (3rd edition). Thousand Oaks, CA: Sage. 